besides popularizing research, Sayce effected decipherments of great importance in several directions and pointed out for the first time historical facts of a revolutionary character. Unfortunately he made the Higher Critics of the Bible the principal butt for attack, and it must be confessed that here he actually sacrificed research and scholarship to a fleeting popularity. The truth prevails and must prevail.

Professor Sayce joined the Royal Asiatic Society in 1874, and contributed to its JourNaL some of his finest work. Especial mention must be made of his treatise on the tenses of the Assyrian verb (1877) and his triumphant decipherment of the Vannic inscriptions from 1882 onward. Down to the time of his death he was writing reviews and articles for the Jounnal. At that time there survived only one member who was senior to him. He served long on the Council, and in 1925 the Society awarded to him its triennial gold medal. The Society of Biblical Archæology, however, of which he was President for many years, claimed his most constant service from its foundation in 1872 to its absorption by the Royal Asiatic Society in 1919.

F. Ll. Griffith.

\title{
Archibald Henry Sayce as Assyriologist
}

Dr. A. H. Sayce, Emeritus Professor of Assyriology at Oxford, was a Welshman of distinguished and aristocratic lineage. His father held a living in Monmouthshire, but the family was long attached to Bristol, where his great grandfather built Clifton House under the tower of Clifton Church.

His early youth was marked by remarkable precocity. He was reading Homer and Virgil at the age of ten, and before he entered Queen's College, Oxford, at the age of 18 he had read some Egyptian, Hebrew, Sanskrit, and the discoveries of Grotefend, Rawlinson, Hincks, and Oppert. An article on the decipherment of the Persian and Babylonian versions of 
the Behistun rock inscription of Darius, written before he entered the University, showed that he already possessed a firm grasp of the problem of Cuneiform studies, and Hincks endeavoured to discover who this remarkable young man was.

He became a Classical Scholar of Queen's, and on graduation was elected a fellow and tutor in 1869. His first contribution was the well-known article "An Accadian Seal" (of Dangi), Journal Philology, 1870, in which he discovered many of the linguistic principles of Sumerian. This priority of insight into the difficulties of Sumerian was admitted by Lenormant and Haupt. At this early stage of his career Sayce already revealed that strange trait of mind which characterized his whole long life. He might have persisted in this subject and become one of the founders of scientific Accadian and Sumerian philology. No man living, with the possible exception of Jules Oppert, had such an encyclopædic linguistic equipment as he; his eyes were too poor to copy texts, but he had the excellent copies of Norris, Pinches, and George Smith to use. He did not continue his Sumerian studies. Indo-Germanic philology now occupied most of his attention, and he became Deputy Professor to Max Müller in IndoGermanic Philology at Oxford, publishing his opus magnum, Introduction to the Science of Language (1880), two thick volumes, which attained to a third edition. Pari passu with his exhausting work on Aryan languages he continued his Cuneiform studies and was the first interpreter of astronomical texts, Proceedings of the Society of Biblical Archoology, 1874, pp. 145-339. In 1875 appeared his Elementary Grammar of the Assyrian Language, and he founded the Records of the Past, 1873-8, in which he offered translations and interpretations of Accadian texts. A revised edition of these eleven small volumes (1888-1892) contained selections of the Amarna Letters. This practically ended his original contributions to pure Assyriology.

His brilliant work on the Elamitic version of the Darius inscription which he was lead to undertake in 1874 by Layard's 
discovery of Cuneiform tablets at Mal-Amir helped to lay the foundations of Elamitic studies. The interpretation of the Mal-Amir tablets was published in PSBA. 1874, pp. 465-485, and he seems to have been the first to discover the linguistic nature of the second version of the Behistum inscription. The name "Elamitic" belongs to him. Again, at the Sixth Congress of Orientalists (1885), he read the Inscriptions of Mal-Amir, vol. i, 639-756. His decipherment of the language of the empire of Urartu, whose ancient capital was Van in Armenia in the ninth-eighth centuries, was a linguistic feat of astonishing accuracy. Without any bilingual text he made a successful outline of the grammar and translated some of the Cuneiform texts of that lost kingdom. This is an agglutinative language, and here Sayce's immense range of languages, including Basque, Hungarian, Polish, Turkish, and Mongolian, gave him an advantage not then possessed by any living scholar. This remarkable work was published in JRAS. 1882, pp. 377-732. When de Morgan and later Belck found a bilingual Vannic-Assyrian inscription in the pass of Kelichin, Sayce's decipherment was found to be in the main correct.

In 1872 he worked on Karian and published his results, Transactions of the Royal Society of Literature, and PSBA. 1886, pp. 112-166. His work on the Greek alphabet became one of the accepted acquisitions of Greek Epigraphy. The undeciphered Mitanni language attracted his attention in 1888 , and he offered an interpretation simultaneously with Jensen and Brünnow in Zeitschrift für Assyriologie (1890). He has for over fifty years devoted his attention to the pictographic script of Hittite, with admittedly great insight and some success. That problem has now been somewhat advanced by the recent works of Forrer, Bosert, Frank, and Gelb. They all acknowledge certain discoveries by Sayce. It is lamentable that his continuous absence from his books lost him the opportunity of being the decipherer of the Hittite language as written in the readable Cuneiform script of the 
ancient Hittite capital at Boghazkeui. This distinction fell to Hrozný, of Prague.

From the point of view of an Assyriologist Sayce must be reckoned as one of the most remarkable geniuses of the heroic age of the subject. When the science of Accadian, Sumerian, Elamitic, and Hittite philology became exact sciences the younger generation developed a tendency either to forget or to underestimate the services of this fine scholar of the old school. There was no trace of jealousy or anything approaching to bad manners in his whole career. He could not specialize; it was not in his nature. The scientific development of Assyriology he left to others. And then that remarkable man, Rudolf Brünnow, son of the Astronomer Royal of Ireland, came to Oxford, and wrote his $A$ Classified List of All Simple and Compound Cuneiform Ideographs. This book, which will always remain one of the foundation stones of Assyriology, was published in 1887. If Oxford had retained Brünnow, who, with Delitzsch, on the strictly scientific side, was undoubtedly the greatest Cuneiform scholar of that period, the whole course of Assyriology in England would have taken a more serious direction. But he became professor in Bonn, turned his attention to Arabic, and ended his days as professor of Semitic languages in Princeton. Oxford, however, gave him the peace and quiet scholastic surroundings necessary to produce this great book, and he was within easy access to the collections of the British Museum. Oxford tradition, therefore, must claim Sayce and Rudolf Brünnow, two men of widely diverse ability and. both necessary to the progress of a subject so vast and intricate, where the decipherer must precede the strict scientist. Naturally the younger generation know the name of Brünnow and cite him almost daily. Sayce's immense services are easily forgotten by those whose plodding ways exclude the appreciation of genius.

I have known Sayce very intimately since 1907. His immense range of knowledge, always ready to hand because 
of his phenomenal memory, was not so obvious in his published work as in his private conversation. He could write good prose in at least twenty ancient and modern languages. This aristocratic scholar of stately manners retained his wonderful memory and interest in Oriental scholarship to his last days. He was reading Ras Shamrā Phœnician texts in his eighty-eighth year, annotating them from memory in Arabic, Assyrian, Hebrew, and Phœnician even after he was stricken by his last fatal illness. I saw him several times within a few days of his death, and when I left him the last question he asked was "When will more Ras Shamrā texts be published ?" It was a fitting end to the life of a great man whose mind was ever attracted by the appearance of new languages and scripts. Ras Shamrā, at the end of his life, had yielded the texts of the early Phœnician language in a strange Cuneiform alphabet. Such a problem was precisely the kind which was food to his soul. It should finally be said for the benefit of many critics that I never heard Sayce speak harshly of those who soundly denounced his work. He himself frequently admitted his mistakes, and certainly in his application of Assyriology to the Old Testament in opposition to the rising school of Hebraists he had the entire opinion of the Assyriologists against him. This does not concern his brilliant work as a decipherer ; decipherment was his métier and on this his reputation must rest.

S. LANGDON. 